\title{
ACUTE CERVICAL EPIDURAL HEMATOMA
}

\author{
CASE REPORT
}

\author{
GUILHERME BORGES*, LEONARDO BONILHA**, MARCOS VINICIUS CALFAT MALDAUM **, \\ JOSÉ RIBEIRO MENEZES ***, VERONNICA ZANARDI***
}

\begin{abstract}
A 74 year-old patient with a nocturnal onset of neck and chest pain was brought to an emergency clinic. Physical examination and cardiac assessment were normal. Three hours after the addmittance, a flaccid paralysis of the four limbs supervened. Suspecting of an unusual onset of central nervous system infection, a lumbar puncture was performed, yielding $20 \mathrm{ml}$ of normal cerebrospinal fluid. Thirty oinutes after the puncture, the patient completely regained neurological funcion. He was then referred to a General Hospital where a computed tomography (CT) scan was done showing a large cervical epidural bleeding in the posterolateral region of $\mathrm{C} 4 / \mathrm{C} 5$ extending to $\mathrm{C} 7 / \mathrm{Th} 1$, along with a $\mathrm{C} 6$ vertebral body hemangioma. A magnetic resonance imaging revealed the same CT findings. A normal selective angiography of vertebral arteries, carotid arteries and thyreocervical trunk was carried out. Spontaneous spinal epidural hematoma (ASSEH) is a rare but dramatic cause of neurological impairment. In this article we report a fortunate case of complete recovery after an unusual spine cord decompression. We also review the current literature concerning diagnosis and treatment of ASSEH.
\end{abstract}

KEY WORDS: spontaneous spinal epidural hematoma, spinal cord compression.

\section{Hematoma epidural cervical agudo: relato de caso}

RESUMO - Paciente de 74 anos acordou à noite sentindo fortes dores na região da nuca acompanhadas de ansiedade e desconforto torácico e respiratório. A internação emergencial em clinica cardiológica não demonstrou problemas cardíacos. Com a progressão do quadro neurológico traduzida por quadriplegia severa foi realizada uma punção lombar para afastar hipótese de meningite, sendo retirados cerca de $20 \mathrm{ml}$ de liquor. Trinta minutos imediatamente após a punção lombar foi observada completa remissão do déficit neurológico. Transferido para um hospital geral a tomografia computadorizada demonstrou extenso hematoma epidural espinal em nivel C4/ C5 com extensão a C7/Th1, bem como hemangioma do sexto corpo vertebral (C6). A ressonância magnética demonstrou as mesmas lesões. Observando-se os parâmetros clínicos e neurológicos, optou-se por tratamento conservador. Dezoito meses após este episódio o paciente se apresenta normal, sem deficit residual. Neste artigo, relatamos um caso de completa recuperação de déficit neurológico devido a hematoma epidural espinal, após forma não usual de descompressão medular.

PALAVRAS-CHAVE: hematoma epidural espinal espontâneo, compressão medular.

Acute spontaneous spinal epidural hematoma (ASSEH) is a dramatic condition that may produce severe neurologic deficit. Cervical spontaneuos spinal hematoma is a rare cause of acute devasting neurological symptoms. Spine pain is a sentinel symptom that may precede neurologic deterioration. While time-costing diagnostic procedures are carried out, spinal cord compression persists and neurologic function impairement ensues. Fatal spontaneous cervical spinal hematoma

Faculdade de Ciências Médicas da Universidade de Campinas (UNICAMP), Disciplina de Neurocirurgia e Departamento de Radiologia, *Professor Doutor - Disciplina de Neurocirurgia, **Médico Residente - Disciplina de Neurocirurgia, ***Professor Doutor - Departamento de Radiologia. Aceite: 14-abril-2000.

Dr. Guilherme Borges - Rua Barão Geraldo de Rezende 282 / 24 - 13020-440 Campinas SP-Brasil. E-mail: gborges@correionet.com.br 
has been previously described in the literature. Early diagnosis and subsequent emergency surgery is the treatment of choice in this serious condition ${ }^{1}$.

We report a case of ASSEH with recovery after unusual spinal cord decompression.

\section{CASE}

A 74-year old man with a previous medical history of embolic strokes due to unknown source, was brought to the cardiac emergency unit after having woken up during the night with a severe pain in posterior neck region. An emergency physician was encharged of the case. During physical examination, the patient was found to be mildly anxious due to the pain. His current medication were platelets antiaggregants and angiotensin converting enzyme inhibitor. He also had a history of having used anticoagulants for two months, three months earlier. Three normal electrocardiograms during the pain crisis were performed. Cardiac enzymes were normal. Two hours after the admittance, he began to develop mild motor and sensory deficits in his lower and upper extremities. Symptomatology progressed quickly, for he was soon completely paralyzed. Since clinical findings were not specific, a lumbar puncture was then performed to rule out central nervous system (CNS) infection. Aproximatelly $20 \mathrm{ml}$ of clear cerebrospinal fluid (CSF) were drained; laboratory analysis revealed normal cell and protein contents.

Surprisingly, during the 30 minutes following the puncture he recovered his sensorimotor function to the normality. He was then referred to a General Hospital where a neurosurgical evaluation was performed. Over the next 18 hours a computed tomography (CT) scan was realized showing a large cervical epidural bleeding in the posterolateral region of $\mathrm{C} 4 / \mathrm{C} 5$ extending to $\mathrm{C} 7 / \mathrm{Th} 1$, and a vertebral body hemangioma of $\mathrm{C} 6$, without signs of bleeding (Fig $1 \mathrm{~A}$ and $\mathrm{B}$ ). A magnetic resonance imaging (MRI) was also performed, confirming the same CT findings (Fig $2 \mathrm{~A}$ and B). Five days after the admission he was discharged walking normally. Two days later, a selective angiography of vertebral arteries, carotid arteries and thyreocervical trunk was carried out, not showing abnormalities despite a little blush on the venous complex at C4/C5 level, considered to be a normal finding (Fig 3). A MRI realized 45 days after the admission was normal (Fig 4). In his last follow-up, 18 months after the incident, he persisted without neurologic deficits.

\section{DISCUSSION}

Spontaneous spinal epidural hematoma is seldom the cause of spinal cord compression. It was first described by Blauby in $1808^{2,3}$. Acute spinal epidural hematoma can be classified as spontaneous or secondary and traumatic ${ }^{4}$. ASSEH frequently occurs associated with causative factors such as coagulopathies, pregnancy, infection, hypertension, neoplasm or rupture of arteriovenous malformations and vertebral body hemangioma ${ }^{4}$. Anticoagulant therapy is one of the commonest causes of spinal hematoma ${ }^{5}$. Thrombolysis for acute myocardial infartation may be as well an

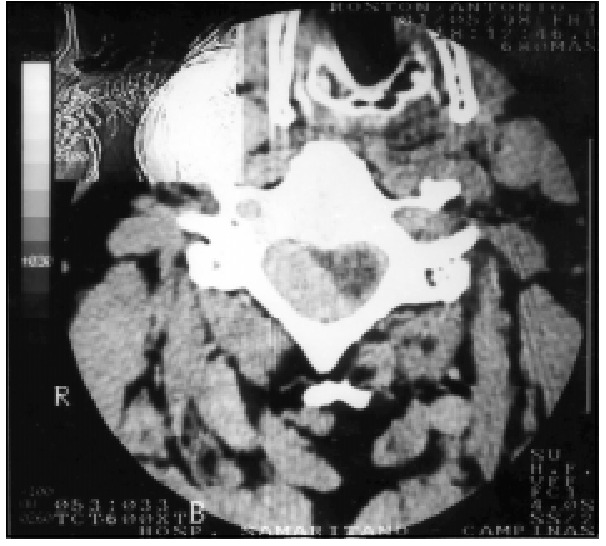

Fig 1A. CT scan showing epidural hematoma in the region of cervical spine between $C 5$ and Th1.

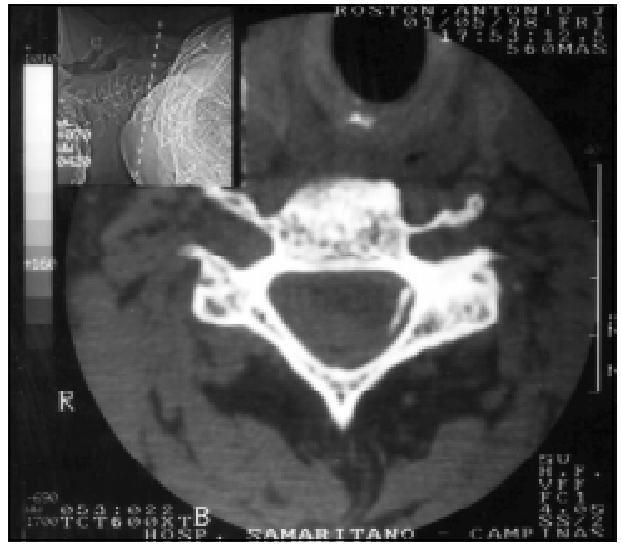

Fig 1B. CT scan showing vertebral body hemangioma of C6. 


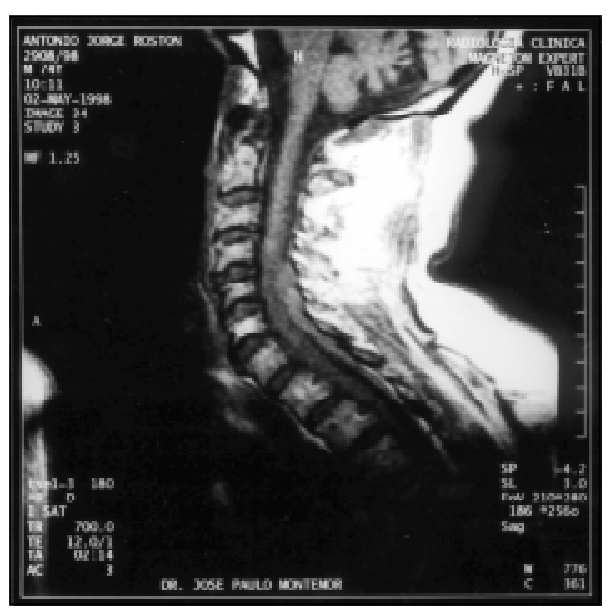

Fig 2A. T1 weighted MRI showing right postero lateral epidural hematoma.

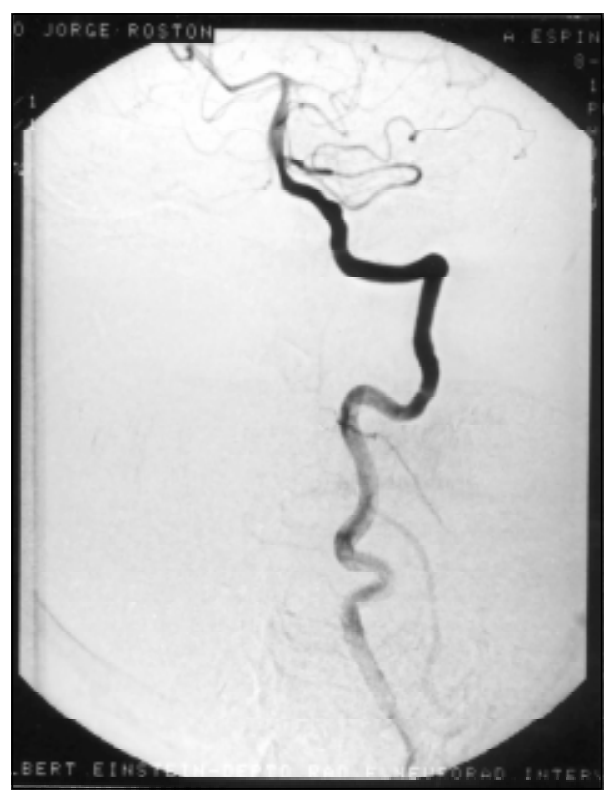

Fig 3. Selective angiography of right vertebral artery showing normal right anterior spinal artery without signs of malformation.

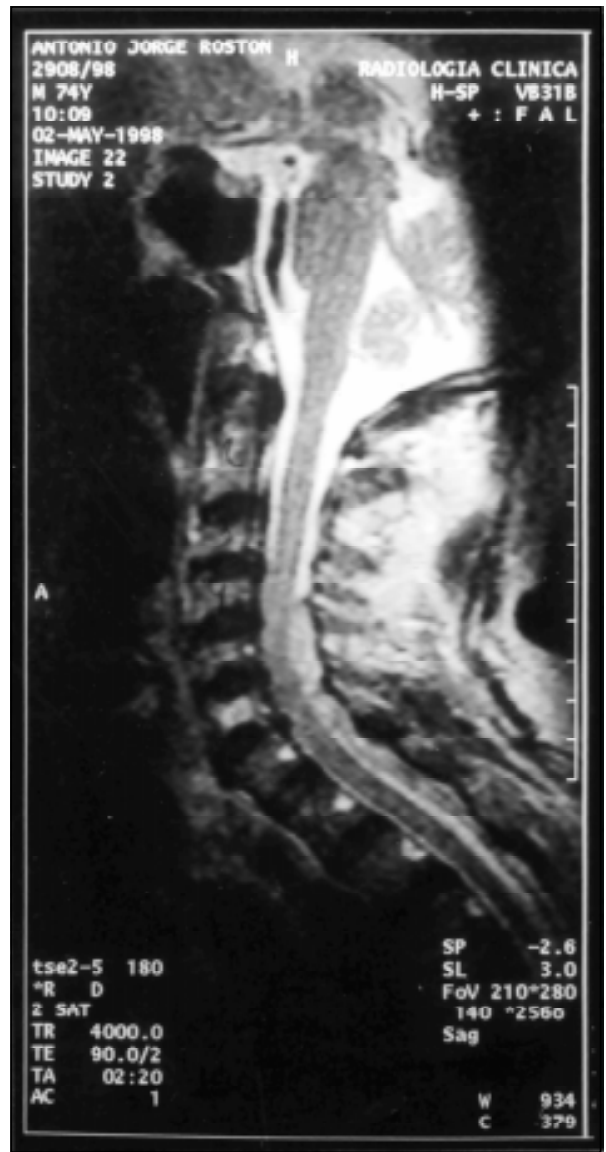

Fig 2B. T2 weighted MRI showing right postero lateral epidural hematoma.

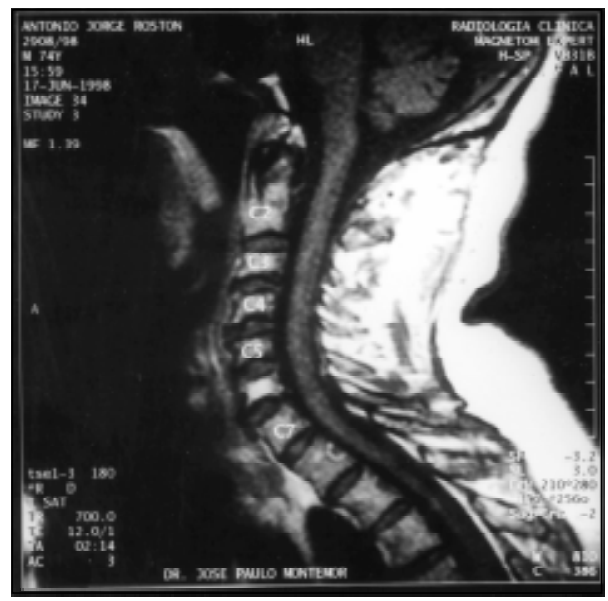

Fig 4. T1 weighted MRI showing complete resolution of the epidural hematoma. 
important factor. The first fatal case of spontaneous spinal epidural hematoma following thrombolysis was reported in the literature by Cohen et al. ${ }^{1}$.

The traumatic hematoma may supervene after major and minor trauma; the latter including mild movements which may strecht the free arteries beyond their elastic tolerance, causing their rupture. The diagnosis of ASSEH is frequently based upon severe pain of acute onset in the spinal region, representing a sentinel symptom that may precede neurological findings. Neurological impairment occurs within 12 hours and is often followed by rapid progression to complete paralysis $\mathrm{s}^{4,6,7}$. Despite the severity of the initial symptoms, relief of the spinal cord compression must take place first, postponing further timecosting investigation. In the past myelography has been advocated as the first choice method for diagnosis, along with CSF analysis with complete manometric manoeuvre, being replaced in the 80's by CT scan, which was then the modality of choice for detecting cervical epidural hematomas ${ }^{6,8-10}$. Nowadays MRI provides a rapid and nonivasive method for direct evaluation of the spinal cord after injury and bleeding ${ }^{11-14}$. MRI is the current diagnostic modality of choice and when performed within minutes or hours after cervical spinal cord injuries may permit quick intervention and convey better prognosis.

According to studies published hitherto the commonest site for ASSEH is the thoracic spine, while in the cervical region $90 \%$ of cases of ASSEH are located in highly mobile C6-C7 segment ${ }^{5,8,15}$. However, some studies such as a 17 cases retrospective study published by Sklar et al. ${ }^{4}$ have suggested that the cervical spine may be the most common region of bleeding, opposed to the thoracic spine.

Although the source of bleeding has never been clarified, it has usually been assumed to be of venous origin ${ }^{13}$. The first case of cervical anterior cord syndrome as a result of a bleeding arteriovenous malformation in the cervical epidural space was reported in $1980^{16}$. The spinal epidural venous network is believed to be the major source of ASSEH since posterior hematomas are more frequent than anterior hematomas. Also, the segmental distribution of ASSEH and the anatomical aspects of the internal vertebral venous plexus such as valveless and thin-walled vessels suggest a venous origin of bleeding ${ }^{14}$. However, the venous pressure in the epidural veins of the cervical region is low if a relaxed person assumes upright position. Also, regardless of position and degree of relaxation, the pressure in these veins is less than the intrathecal pressure at the same level. Therefore, an hemorrhage from an epidural vein would not significantly be responsible for acute compression of the spinal cord. An arterial source for the ASSEH bleeding is advocated by some authors because of the proximity of the epidural arteries with nerve roots and the reported cases with radicular pain as a first symptom ${ }^{1}$. In fact, the main source of bleeding is yet to be accurately defined.

In a literature review of 333 operated cases Groen and van Alphen ${ }^{17}$ concluded that the major factors determining neurological recovery after ASSEH are the localization of the hematoma, the preoperative neurological condition and the operative interval (elapsed time for surgery). The overall mortality in his series was $8 \%$. In another article, Beatty and Winston ${ }^{7}$ show a mortality of $16 \%$ of 43 surgically treated patients. Overall many studies demonstrate that the surgical procedure must be done immediately and that the surgical results are quite gratifyng ${ }^{12,17-20}$. Surgery may not be necessary if patient demonstrates clinical improvement along with improvement in the image findings ${ }^{12,20}$, like our own case.

As supported by previous articles, in a elderly patient, symptoms of central nervous system infections can be very misleading and confusing ${ }^{21}$. In this article we report a case in which a lifesaving spinal cord decompression was carried out by an emergency physician through a lumbar puncture aiming to rule out a CNS infection in a patient with neck pain and nonspecific findings. Albeit the physician had not hypothesized that symptoms could have been attributable to a compression of the spinal cord, he fortunately ended up decompressing the central nervous system and hastening a functional recovery.

Supported by the image findings and the physical assessment, we assumed that the hematoma had an spontaneous origin. We considered that the vertebral body hemangioma was a casual finding, since it was depicted to be completely enclosed in the sixth cervical vertebra without signs of bleeding. 
When the neurosurgical team was finally recalled, we decided not to operate on the patient according to well established literature reports indicating not to do so when functions have been recovered and the patient is stable ${ }^{12,20}$.

We want to demonstrate in this article that rare fortunate cases of spinal cord decompression and complete neurological recovery may supervene when the decompression is performed through a lumbar puncture. Nevertheless, the lumbar puncture must not be considered a standard form of treatment, which may then be carried out, as stressed above, through surgical approaches whenever the necessary, what means instability and persistence of neurological symptoms ${ }^{12,20}$.

In conclusion, ASSEH is a rare condition with a rather unfavorable prognosis if left untreated. Suspicion must be raised whenever mild or severe neck pain ensues abruptly and is followed by neurologic symptoms. The major site and the most common source of bleeding are yet to be clarified. CT scan and MRI are the most accurate methods for precise diagnosis. Once defined the site of bleeding, surgery must be performed unless the patient is stable and symptom-free. However, rapid intervention involving spinal cord decompression through CSF lumbar drainage may avoid further damage. Prognosis vary depending on patient's previous medical conditions, but it may be stressed that suspection and rapid intervention are key points for better recovery.

\section{REFERENCES}

1. Cohen JE, Ginsberg HJ, Emery D, Schwarz ML. Fatal spontaneous spinal epidural hematoma following thrombolysis for myocardial infarction. Surg Neurol 1998;49:520-523.

2. Scheil F, Larkamp U, Mutharoglu U. Das spontane spinale Hämatom. Neurochirurgia 1990;33:45-49.

3. Pendl G, Ganelberger JA, Horcajada J. Spinal extradural hematoma. Acta Neurochirurg 1971;24:437-439.

4. Sklar EML, Post JMD, Falcone S. MRI of acute spinal epidural hematomas. J Comput Assist Tomogr 1999;23:238-243.

5. Post MJD, Seminer DS, Quencer RM. CT diagnosis of spinal epidural hematoma. AJNR 1982;3:190-192.

6. Haykal HÁ, Wang A-M, Zamani AA, Rumbaugh CL. Computed tomography of spontaneous acute cervical epidural hematoma. J Comput Assist Tomogr 1984;8:229-231.

7. Beatty RM, Winston KR. Spontaneous cervical epidural hematoma. J Neurosurg 1984;61:143-148

8. Pear BL. Spinal epidural hematoma. AJR 1972;115:155-164.

9. Scott BB, Quisling RG, Miller CA, Kindt GW. Spinal epidural hematoma. JAMA 1976;235:513-515

10. Vallee B, Besson G, Gaudin J, Person H, Le Fur JM, Le Guyader J. Spontaneous spinal epidural hematoma in a 22-monthold girl. J Neurosurg 1982;56:135-138.

11. Selden NR, Quint DJ, Patel N, D'Arcy HS, Papadopoulos SM. Emergency magnetic resonance imaging of cervical spinal cord injuries: clinical correlation and prognosis. Neurosurgery 1999;44:785-793.

12. Lefranc F, David Philippe, Brotchi J, Witte DE. Traumatic epidural hematoma of the cervical spine: magnetic resonance imaging diagnosis and spontaneous resolution: case report. Neurosurgery 1999;44:408-411.

13. Awada A, Russell N, Al-Fayez N, Naufal R, Al-Kohlani H. Spontaneous cervical epidural hematoma: case report. Spinal Cord 1998;36:71-72.

14. Miyagi Y, Miyazono M, Kamikaseda K. Spinal epidural vascular malformation presenting in association with a spontaneously resolved acute epidural hematoma. J Neurosurg 1998;88:909-911.

15. Lanzieri CF, Sacher M, Socodinik P, Moser F. CT myelography of spontaneuos spinal epidural hematoma: case report. J Comput Assist Tomogr 1985; 9:393-394.

16. Foo D, Chang YC, Rossier AB. Spontaneous cervical epidural hemorrhage, anterior cord syndrome, and familial vascular malformation: case report. Neurology 1980;30:308-311.

17. Groen RJM, van Alphen HAM.Operative treatment of spontaneous spinal epidural hematomas: a study of the factors determining postoperative outcome. Neurosurgery 1996;39:494-508.

18. Correa AV, Beasley BAL. Spontaneous cervical epidural hematoma with complete recovery. Surg Neurol 1978;10:227-228.

19. Bareno EE, Schlamich MA. L'hématome épidural cervical spontané - à propos d'un cas. Neurochirurgie 1987;33:66-70

20. Muhonen MG, Piper JG, Moore AS, Menezes AH. Cervical epidural hematoma secondary to an extradural vascular malformation in an infant: case report. Neurosurgery 1995;36:585-588.

21. Attia J, Hatala R, Cook DJ, Wong JG. Does this adult patient have acute meningitis? JAMA 1999;282:175-181. 